Business History Review

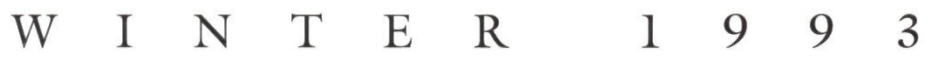

\title{
RECORDING SOUND ON WIRE
}

Design of New Instrument for Office and Home Permits Quick Change of Wire Spool and Accurately Controlled Playbacks with Tone of High Quality 
Front Cover: Magnetic Tape's Competition

Although the value of magnetic tape as a recording medium for audio, visual, and data storage is wellknown in the 1990s, the basic technology, available since the late nineteenth century, remained largely undeveloped in the United States before the Second World War. When German magnetic tape and recording technology was brought to the United States in the wake of the war, companies such as the Radio Corporation of America (RCA) had embarked on plans to produce recorders using wire as a medium, and it was not at all clear that a consumer market in tape equipment would develop. RCA advertised the wire recorder shown in the illustration as "an instrument finding extensive use in business offices ... [and providing] ideal, inexpensive means for recording favorite radio programs, family gatherings or the sounds of baby's first words." (Photograph and quotation are from Radio Age [RCA's company magazine] 7 [Jan. 1948]: 18.)

For an article examining one U.S. pioneer in magnetic tape production, see pp. 589-622.

Back cover: A Cascade of Titles from the Recipients of the 1993 Nobel Prize in Economics

The writings of Robert Fogel and Douglass North, whose most well known books are displayed here, have always generated a great deal of discussion among both economists and historians. To mark the occasion of their selection as recipients of the Bank of Sweden Prize in Economic Science in Honor of Alfred Nobel, the journal asked another well known economic historian, William Parker, to provide a commentary. For the result, see pp. 623-636.

1993 by The President and Fellows of Harvard College.

All rights reserved.

ISSN $0007-6805$

Second class postage paid at Boston, Mass. 


\section{Business History Review}

Published Quarterly by the Harvard Business School Volume 67 Number 4 Winter 1993

Acting EDITOR - Jack High, Harvard University Associate EDITOR - Patricia Denault, Harvard University

Business Manager - Ann Chaney, Harvard University

EDITORIAL ADVISORY BOARD

Mansel Blackford, Ohio State University

Louis P. Cain, Loyola University of Chicago

Alfred D. Chandler, Jr., Harvard University

Rainer Fremdling, University of Groningen

Tony Freyer, University of Alabama

Patrick Fridenson, École des Hautes Études

Mark Fruin, University of British Columbia

Thomas P. Hughes, University of Pennsylvania

William Lazonick, University of Massachusetts, Lowell

Thomas K. McCraw, Harvard University

John J. McCusker, Trinity University

John P. McKay, University of Illinois, Urbana-Champaign

Roland Marchand, University of California, Davis

H. V. Nelles, York University

Daniel Nelson, University of Akron

Richard S. Rosenbloom, Harvard University

Philip Scranton, Rutgers University, Camden

Richard S. Tedlow, Harvard University

Richard H. K. Vietor, Harvard University

Mira Wilkins, Florida International University

Takeshi Yuzawa, Gakushuin University 
The Business History Review is published in the spring, summer, autumn, and winter by the Harvard Business School Publishing Corporation and is printed at the Office of the University Publisher.

- Manuscripts, books for review, and all editorial correspondence should be sent to

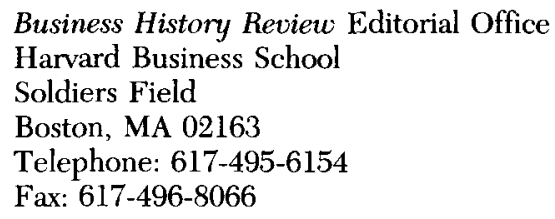

- Queries regarding advertising and subscriptions, as well as all changes of address, should be sent to the business manager, Ann Chaney, at the same address.

. Correspondence regarding rights and permissions should be addressed to

\author{
Audrey Barrett \\ Permissions Editor \\ HBSPC \\ Harvard Business School \\ Boston, MA 02163
}

\title{
- Annual Subscription Rates
}

Individuals

$\$ 35.00$

Institutions

$\$ 75.00$

Students (U.S. \& Canada, with valid ID) $\$ 20.00$

All subscriptions outside the U.S. and Canada $\$ \$ 75.00$

- Many issues of volumes 59-66 (1985-92) are available from our office for $\$ 15.00$ per issue or $\$ 60.00$ per volume. Please write for details.

- Business History Review articles are listed in Business Methods Index, Book Review Index, the Journal of Economic Literature, Historical Abstracts, America-History and Life, and ABI/INFORM.

- Notice of failure to receive issues must reach the office no later than six months after the date of mailing. Postmaster: Send address changes to Business History Review, Harvard Business School, Boston, MA 02163.

- The paper used in this journal meets the minimum requirements of the American National Standard for Permanence of Paper for Printed Library Materials, Z.39.48 and is $50 \%$ recycled, $10 \%$ post-consumer. 


\section{O N T E N T S}

\section{Articles}

Clayton M. Christensen The Rigid Disk Drive Industry: A History of Commercial and Technological Turbulence . 531

David L. Morton "The Rusty Ribbon": John Herbert Orr and the Making of the Magnetic Recording Industry, 1945-1960 • 589

\section{Survers and Debates}

William N. Parker A "New" Business History? A Commentary on the 1993 Nobel Prize in Economics • 623

\section{Editor's CORNer • 637}

\section{Book Reviews}

Jonathan Brown and Mary B. Rose, eds., Entrepreneurship, Networks and Modern Business. Reviewed by W. D. Rubinstein • 691

Jonathan C. Brown, Oil and Revolution in Mexico. Reviewed by Richard H. K. Vietor • 681

Eric Bussière, Paribas, 1872-1992: Europe and the World. Reviewed by Youssef Cassis - 698

J. M. Carter, Commercial Bank Liquidity Management, Discretionary Reserve Behavior, and the Allocation of Credit, 1863-1913. Reviewed by Richard H. Keehn $\cdot 653$

Linda Clarke, Building Capitalism: Historical Change and the Labour Process in the Production of the Built Environment.

Reviewed by Carol E. Heim - 687

James D. Dilts, The Great Road: The Building of the Baltimore and Ohio, the Nation's First Railroad, 1828-1853.

Reviewed by John F. Stover - 645

Claude S. Fischer, America Calling: A Social History of the Telephone to 1940. Reviewed by David F. Weiman - 660

Charles E. Freedeman, The Triumph of Corporate Capitalism in France, 1867-1914. Reviewed by Lenard R. Berlanstein • 697 
Walter Galenson, Labor and Economic Growth in Five Asian

Countries: South Korea, Malaysia, Taiwan, Thailand, and the Philippines. Reviewed by Hagen Koo • 702

John S. Garner, ed., The Company Town: Architecture and Society in the Early Industrial Age. Reviewed by Joseph Melling • 685

W. R. Garside, ed., Capitalism in Crisis: International Responses to the Great Depression. Reviewed by Kenneth Mouré • 689

Stanley C. Hollander and Richard Germain, Was There a Pepsi

Generation before Pepsi Discovered It? Youth-Based

Segmentation in Marketing. Reviewed by Thomas Frank • 670

Kris Inwood, ed., Farm, Factory and Fortune: New Studies in the

Economic History of the Maritime Provinces.

Reviewed by Christopher Armstrong $\cdot 680$

Ellen D. Langill, Foley \& Lardner, Attorneys at Law, 1842-1992. Reviewed by Tony Freyer • 664

Nelson Lichtenstein and Howell John Harris, eds., Industrial

Democracy in America: The Ambiguous Promise.

Reviewed by Christopher L. Tomlins • 656

Stephan H. Lindner, Das Reichskommissariat für die Behandlung feindlichen Vermögens im Zweiten Weltkrieg: Eine Studie zur

Verwaltungs-, Rechts- und Wirtschaftsgeschichte des nationalsozialistischen Deutschlands.

Reviewed by John Gillingham • 701

Alfred L. Malabre, Jr., Lost Prophets: An Insider's History of the Modern Economists. Reviewed by Robert Sobel • 678

Cathie J. Martin, Shifting the Burden: The Struggle over Growth and Corporate Taxation. Reviewed by Paul J. Miranti, Jr. • 673

William M. Mathew, ed., Agriculture, Geology, and Society in Antebellum South Carolina: The Private Diary of

Edmund Ruffin, 1843. Reviewed by Lacy K. Ford • 643

Timothy J. Muris, David T. Scheffman, and Pablo T. Spiller, Strategy, Structure, and Antitrust in the Carbonated Soft-Drink Industry.

Reviewed by Robert D. Tollison $\cdot 668$

Daniel Nelson, ed., A Mental Revolution: Scientific Management since Taylor. Reviewed by Hindy Lauer Schachter • 655 
Harold T. Parker, An Administrative Bureau during the Old Regime: The Bureau of Commerce and Its Relations to French Industry from

May 1781 to November 1783. Reviewed by J. R. Harris • 694

Laura Randall, The Political Economy of Brazilian Oil. Reviewed by John D. Wirth • 683

George Robb, White-Collar Crime in Modern England: Financial Fraud and Business Morality, 1845-1929. Reviewed by Geoffrey Channon • 693

David Rogers, The Future of American Banking: Managing for Change. Reviewed by Samuel L. Hayes III • 676

H. Lee Scamehom, Mill \& Mine: The CF \& I in the Twentieth Century. Reviewed by Price V. Fishback • 662

Ronald Schultz, The Republic of Labor: Philadelphia Artisans and the Politics of Class, 1720-1830. Reviewed by Paul A. Gilje • 641

Jay P. Spenser, Vertical Challenge: The Hiller Aircraft Story. Reviewed by William F. Trimble • 666

Julius E. Thompson, The Black Press in Mississippi, 1865-1985. Reviewed by Henry L. Suggs • 651

J. Samuel Walker, Containing the Atom: Nuclear Regulation in a Changing Environment, 1963-1971. Reviewed by Brian Balogh • 671

Lynn Willoughby, Fair to Middlin': The Antebellum Cotton Trade of the Apalachicola/Chattahoochee River Valley. Reviewed by John Killick • 647

Ronald J. Zboray, A Fictive People: Antebellum Economic Development and the American Reading Public. Reviewed by Timothy H. Scherman $\cdot 649$

INDEX To VoLume $67 \cdot 704$ 


\section{CONTRIBUTORS}

Clayton $M$. Christensen is assistant professor of business administration at the Harvard Business School. He holds a B.A. with highest honors in economics from Brigham Young University (1975), an M.Phil. from Oxford University, where he studied as a Rhodes Scholar (1977), and an MBA (1979) and DBA (1992) from the Harvard Business School. From 1979 to 1984 , Christensen worked as a consultant and project manager with the Boston Consulting Group, where he was instrumental in founding the firm's manufacturing strategy consulting practice. He served in 1982-83 as a White House Fellow, working as an assistant to transportation secretaries Drew Lewis and Elizabeth Dole. Prior to joining the HBS faculty, Christensen was chairman and president of Ceramics Process Systems Corporation, a firm that he cofounded with several MIT faculty members in 1984; CPS is a leading developer of products and manufacturing processes using high-technology ceramics materials. Christensen's research and writing interests center on the management of technological innovation.

David L. Morton is at present a Ph.D. candidate in the School of History, Technology, and Society at the Georgia Institute of Technology. He received an A.B. in history from the University of Georgia in 1987, an M.A. in history from Auburn University in 1990, and an M.S. in history from the Georgia Insitute of Technology in 1994. His dissertation will address the history of the development and uses of magnetic recording technology in the United States from 1900 to 1965.

William N. Parker is Phillip Golden Bartlett Professor of Economics and Economic History, emeritus, at Yale University. He taught American and European economic history successively at Williams College, the University of North Carolina, and Yale University between 1951 and 1993. He was editor of and contributor to a number of collections in the "new" economic history. His last edited volume, Economic History and the Modern Economist (1986) contains, along with essays by notable economists and economic historians, his view of the history of economic history and its place in 
graduate studies. His own historical essays have been collected in Europe, America, and the Wider World, 2 vols. (1984 and 1991). He is a fellow of the American Academy of Arts and Sciences and of the American Philosophical Society. 


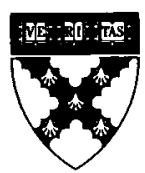

The Editorial Board of the

Business History Review

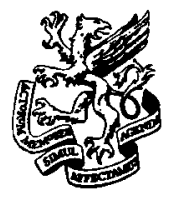

Newcomen Society of the

and the United States

announce the winner of the 1992 NEWCOMEN AWARD IN BUSINESS HISTORY

BEST ARTICLE AWARD:

Richard N. Langlois

University of Connecticut, Storrs

for

"External Economies and Economic Progress: The Case of the Microcomputer Industry"

The Newcomen Award is presented annually to the author of the best article published in the Business History Review. It consists of a scroll and a cash prize of $\$ 300$. The Special Article Award, for the best article written by a graduate student or recent Ph.D. who has not yet published a book in the field of business history, was not given in 1992. The awards are made possible through the generosity and support of the Newcomen Society of the United States. 